\section{Sustainable Transport of Goods Using Combined Transport Solutions: The Case of EU}

\section{Marek Minárik}

University of Economics in Bratislava, Faculty of Commerce, Department of International Trade, Slovakia

marek.minarik@euba.sk

\begin{abstract}
This paper analyzes the importance of bimodal solutions in the rail-road transport of goods with an emphasis on the aspect of ecology within the geographical region of EU-28. Using the panel regression analysis in the period from 2010 to 2019, we are trying to confirm the dependence between the road and rail transport of goods by applying several freight units' measures: the freight transport performance in tonne-kilometres, the freight transport performance in tonne-kilometres per thousand of USD, and the amount of goods transported in thousands of tonnes. The application of data to all selected freight units' measures in the regression models confirms a relationship between road and rail transport. A direct relationship between these two modes of transport confirms the complementarity effect, which means that, in most cases, the goods transport solutions require the combination of road and rail mode, where the railway should be considered as the main transport/carrier, the road transport, however, should have the role of short pre-transport or post-transport. The ecological aspect of such bimodal solutions can also be emphasized since the railway transport is considered as an ecological mode.
\end{abstract}

Keywords: bimodality, combined transport of goods, ecology, European Union

\section{Introduction}

The main objective of state transport policies (Banister, 2018) is to reduce or to eliminate the environmental burden and damage for public health, caused by road freight transport, supporting the most ecological transport modes, such as the railways and inland waterways, which can be used as carriers in combined transport operations (Široký, Schröder \& Gašparík, 2017). This objective is also identified within the European Union's White Paper - Roadmap to a Single European Transport Area - Towards a competitive and resource-efficient transport system. By 2030, 30\% of the road freight over $300 \mathrm{~km}$ (Carboni \& Dalla Chiara, 2018) should shift to other modes, such as rail or waterborne transport (Široký, Schröder \& Gašparík, 2017). The combined transport would be ineffective in the short haulages (Carboni \& Dalla Chiara, 2018) - the loading to be completed requires a certain amount of time.

The analysis in Table 1 is based on strengths and weaknesses of the transport modalities, such as road and rail. These two transportation modes can be characterized
ORIGINAL SCIENTIFIC PAPER

RECEIVED: JUNE 2020

REVISED: FEBRUARY 2021

ACCEPTED: APRIL 2021

DOI: 10.2478/ngoe-2021-0010

UDK: 656:502.131.1(4-6EU)

JEL: M21, R40, Q56

Citation: Minárik, M. (2021). Sustainable Transport of Goods Using Combined Transport Solutions: The Case of EU. Naše gospodarstvo/Our Economy, 67(2), 29-39. DOI: 10.2478/ngoe-2021-0010

\section{NG OE}

\begin{tabular}{c} 
NAŠE GOSPODARSTVO \\
OUR ECONOMY \\
\hline Vol. 67 \\
\hline pp. $29-39$
\end{tabular}


Table 1. Strengths and weaknesses of road and rail transport modes

\begin{tabular}{|c|c|}
\hline \multicolumn{2}{|c|}{ Road transport } \\
\hline Strength & Weaknesses \\
\hline Irreplaceable for very short distances & Limited capacity \\
\hline Irreplaceable in logistics & Unreliable in time \\
\hline Flexible & Dependent on traffic disorders \\
\hline Possible time and cost savings at medium distances & Environmental problems \\
\hline Addressing responsibility & Dependent on the weather \\
\hline Free pricing & Problems in custom transit regime \\
\hline \multicolumn{2}{|c|}{ Railway transport } \\
\hline Strength & Weaknesses \\
\hline Possible time and cost savings at medium and long distances & Less flexibilty \\
\hline More capacity and diverse fleet & Lower operability \\
\hline Exact timetables & Problems with logistics \\
\hline The possibility to achieve higher speeds & Problems with modern forms of business \\
\hline Save and relatively trouble-free & Lower price flexibility \\
\hline Easy border crossing and transit & High investments \\
\hline \multicolumn{2}{|l|}{ Joint responsibility of the participating railways } \\
\hline Environmentally friendly & \\
\hline
\end{tabular}

Source: Hansenová (2007), Furdová and Hansenová (2013)

by the issues of transportation costs, transit time, delay percentage, frequency and free time (Kurtuluş \& Bilge Cetin, 2020). The authors of these five concepts prepared a tailor-made investigation for the Turkish transport sector concerning the modal shift. The result of these intermodal rail-road transport solutions is the doubling of the train frequency and the $50 \%$ reduction of the transit time, depending on the increased frequency. According to Hansenová (2007) and Furdová and Hansenová (2013), road transport is one of the most challenging transportation mode concerning environmental problems, encompassing $\mathrm{CO} 2$ emissions, carbon footprint, etc.

Intermodal solutions, where rail transport is a carrier, embody transport of accompanied (e. g. trucks, trailers and tractors with their drivers) and unaccompanied (e. g. TEU, FEU and other types of containers, swap bodies and semitrailers without their drivers) intermodal transport units, using trains (UNECE, 2018). The intermodal transport units are well-known as loading units in combined transport, defined as objects of transshipment while protecting the goods to be transported (e. g. containers, which can be transported across all transport modes) (INTERREG, 2020). Among the advantages of the use of these type of loading units are economic viability, easy handling, and transshipment, using several types of technology (e. g. rolling Motorway - RoLa,
Roll-on Roll-Off - RoRo, Cargo Beamer, Modalohr or MegaSwingTMDuo), beneficial utilization of space, easier storage, better options for gathering information, statistics and accounting can be underlined (INTERREG, 2020).

During the last ten years (2009-2018), multimodal transport within EU-28 countries has recorded a decline in freight volume relative to GDP. According to Eurostat (2020), the volume of freight multimodal transport relative to GDP in 2018 reached only 96\% compared to the reference year 2010 with a volume of $100 \%$. The most significant decline in the importance of multimodal freight transport can be observed in Estonia (with 47.5\% in 2018, compared to $100 \%$ in 2010), Malta (62.8\% in 2018) and Ireland (66.6\% in 2018). Conversely, the largest increase can be observed in the case of Slovenia (118.4\% in 2018, compared to $100 \%$ in 2010 ), Czech Republic (109.7\% in 2018) and Croatia (103.7\% in 2018). The smallest changes or the greatest stability in terms of volume of freight multimodal transport relative to GDP for the period 2009-2018 can be observed in Lithuania, Belgium, Poland and Spain. Considering the growth of GDP in current prices in euros per capita for the EU-28 countries for the period 2009-2018 (from 24050 EUR to 30 170 EUR), we are convinced that there can be no question of a decline in the importance of multimodal transport. If the volume of freight multimodal transport was expressed 
in absolute values, an increase in the transported volume would be recorded.

Focusing on the rail - road intermodal combined transport, there are some characteristic features and data for the EU-28 countries (UIRR, 2020). Rail freight transport has a relatively high market share in North-Eastern Europe, where it gains more than $25 \%$ of the share of the total modal split. The Western countries like France, United Kingdom or Spain struggle with shifting from road to rail, and the rail freight transport has a relatively low market share, gaining less than $12 \%$ of the share of the total modal split. The market share of the road freight transport is around 74\% within the EU-28 countries. Almost half (48.15\%) of all road transport services are less than $300 \mathrm{~km}$ long, which is another evidence of its effectiveness on the short haulages (Rail Freight, 2019).

Rail freight corridors within the EU-28 countries come out of the European rail transport routes, based on the EU Regulation 913/2010. The principal objective of adopting this regulation was to optimise the use of the densely used European rail network. The five most important intermodal freight lanes in the EU-28 countries are Germany - Italy, Germany - Netherlands, Germany - Czech Republic, Belgium - Italy and Czech Republic - Slovakia (UNECE, 2018).

Slovenia, situated along the Mediterranean and the Baltic Adriatic transport corridors, needs to establish a framework for intermodal transport to ensure effective logistic chains, developing new railway infrastructure at the nodes with other transport modes. These attempts encompass for example the modernization of the port of Koper, railway lines for the leg between Koper and Divača with several tunnels and bridges, as the most expensive investments within this project.

\section{Theoretical Backgrounds}

This paper studies the mutual relationship among the transport modes in the form of a regression analysis, whose outcomes should be a model or models, justifying the significance of the sustainable rail-road combined transport solutions (Matthias et al., 2020). The geographical focus of the study is limited to the EU-28 countries. There are more approaches to the topic of the combined transport, e. g. the definition of IRU (2020): „Combined transport refers to the carriage of goods from one place to another using different means of transport: road for the first and last leg of the journey and rail or water for the rest.“

The United Nations Economic Commission for Europe (2020) defines the combined transport as „intermodal transport where the major part of the European journey is by rail, inland waterways or sea and any initial or final legs carried out by road are as short as possible." Intermodal transport of goods and the high quality of transport infrastructure are crucial aspects of the comparative advantage for logistics (Park, 2020).

Rail-road combined transport is generally considered as an appropriate solution aiming the reduction of externalities with no negative impact on mobility, but its main problem use to be the lack of adequate infrastructure, leading to high costs for operators (Cavallaro et al., 2021). An example of such operators is CTO - combined transport operators which operate within terminals of intermodal transport. The terminals form a crucial part of the whole intermodal chain because they have a high impact on the competitiveness of this kind of transport solutions (Mathisen \& Hanssen, 2014) comparing to no combined transport. The rail transport operates between intermodal terminals. The bimodal rail-road combined transport is a solution for a single rail transport that comprises problems, like less flexibility in accessing terminals from the origin area (e. g. factories) and accessing the destination area (e. g. factories) from terminals (Bierwirth et al., 2014). This accessibility of the bimodal solution is due to the flexible road transport component that is related to the short pre- and post- transportation. The whole process within a bimodal transport solution has a common basis with the intermodal transport units, such as containers, swap bodies and semitrailers. These units are taken by road transport mode to the departing terminal of intermodal transport, transported by rail transport mode to a destination terminal of intermodal transport. They can then continue their journey once again using the road transport mode (UNECE, 2018).

The European Union (European Commission, 2020) regulates the combined transport through the Combined Transport (CT) Directive (Council Directive 92/106/EEC). This regulation aims to develop combined transport operations by reducing authorisation procedures and quantitative restrictions for the combined transport operations and provide financial supports in the form of fiscal incentives for these operations. Combined transport in Europe is dynamically developing and this development from the transport and the environmental policy point of view represents the main points of the EU's strategy. This system for sustainable transport of goods is strongly supported at the level of EU (UIRR, 2020) with more measures which UIRR (2020) define as „the elaboration and preservation of framework conditions to ensure it fair access to the transport market.“

Because of the previously described facts, we will try to confirm our ideas of the existence of the ecological combined transport operations. The outcomes for this research are based on our previous research dedicated to the topic of 
Multimodal Transport of Dangerous Goods and its Impact on the Ecology. It deals with the idea that the ecological aspect of transport is very clear in the transport of dangerous goods (Minárik, 2019). The internet web of Green Modal Transport (2019) emphasizes some facts that are considered as advantages of a modal transfer: environmental, economic and social benefits, reduction of greenhouse gas emissions, sustainable development, reduction of negative impacts on sensitive ecological areas, lesser consumption of non-renewable resources, fuel costs and in general operating costs savings (Hanssen \& Mathisen, 2011), lower impact of the road transport taxes mainly in Germany and France. According to some authors (Forkenbrock, 2001), the external cost of an intermodal train per tonne-km is only $28 \%$ of the external cost of a general freight truck. However, it is verified that intermodal transportation is a profitable alternative to long-distance road transportation (Bierwirth et al., 2014).

\section{Methodology}

The main objective of this article is to analyze the importance of a bimodal rail-road solution in the transport of goods (Bierwirth et al., 2014) with an emphasis on the aspect of ecology within the geographical region of EU-28 countries over the past 10 years, starting with 2010 and finishing with 2019 (the last data available) The objective was achieved by verifying the hypothesis, which was formulated as follows:

\section{H1: The transport of goods in the EU-28 countries is being realized in environmentally friendly combined transport solutions (the combination of the road and railway transport mode), where the road transport depends on railway transport.}

The dependence of road transport on railway transport is analyzed based on different units of measure, which are stated below. The research has geographical limitations for the EU-28 member states (including the United Kingdom). All data come from the OECD (2021) and Eurostat databases (2018, 2020). The analysis proceeds in the form of three regression models. The first model - Pooled OLS analyzes the dependence between the freight transport performance in million of tonne-kilometers of road and rail transport modes. The second model - Fixed-effects analyzes the dependence between the freight transport performance in tonne-kilometers per one thousand units of current USD GDP of road and rail transport modes and the third model - Random-effects analyzes the dependence between the amount of goods in thousand of tonnes transported by road and rail transport modes. The panel regression analysis made in the Gretl statistical program, in all three cases, consists of the independent variables for the rail transport (within the period of 2010 - 2019) and of the dependent variable for the road transport (within the period of 2010 - 2019). The main idea was to identify a possible relationship between the road transport (the road transport is considered as short pre- and post-transports) and rail transport which is considered as a carrier (Rail Freight, 2019).

The existence of a possible direct relationship between these two modes of transport should confirm the complementarity effect, which means that, in most cases, the goods transport solutions require the combination of road and the rail mode. In other words, it could confirm that road transport plays an important role in the pre-transport or post-transport operations within combined transport solutions. The existence of a possible indirect relationship between these two modes of transport should confirm the substitutional effect, which means that, in most cases, the goods transport solutions do not require the combination of road and rail mode and the transport is realized in unimodal road transport substituting the rail transport solution or in unimodal rail transport substituting the road transport solution. There are three cases of the resulting linear regression models, which have the forms set by the equations:

Poled OLS model: $\mathrm{y}_{\mathrm{it}}=\alpha+\beta_{1} \mathrm{x}_{\mathrm{it} 1}+\beta_{2} \mathrm{x}_{\mathrm{it} 2}+\ldots+\beta_{\mathrm{k}} \mathrm{x}_{\mathrm{itk}}+\mathrm{u}_{\mathrm{it}}$

Fixed-effects model: $y_{i t}=\alpha_{i}+\beta_{1} x_{i t 1}+\beta_{2} x_{i t 2}+\ldots+\beta_{k} x_{i t k}+u_{i t}$

Random-effects model: $\mathrm{y}_{\mathrm{it}}=\beta_{1} \mathrm{x}_{\mathrm{it1}}+\beta_{2} \mathrm{x}_{\mathrm{it} 2}+\ldots+\beta_{\mathrm{k}} \mathrm{x}_{\mathrm{itk}}+\left(\alpha_{\mathrm{i}}+\varepsilon_{\mathrm{i}}\right) \mathrm{u}_{\mathrm{it}}$ (3)

\section{Results and Discussion}

We start our research by creating the regression model of dependence of the road freight transport performance in millions of tonne-kilometers on the rail freight transport performance in million of tonne-kilometers. The Pooled OLS model (table 2) was selected in this first phase of the research.

The regression analysis was completed with the following tests: test for normality of residual; Null hypothesis: error is normally distributed. Test statistic: Chi-square(2) $=2.6301$, with p-value $=0.268461$.

White's test for heteroskedasticity; Null hypothesis: heteroskedasticity not present. Test statistic: LM $=1.38581$, with $\mathrm{p}$-value $=\mathrm{P}($ Chi-square $(2)>1.38581)=0.500122$. Since Chi-square $(2)=5.99146(5.99146>1.38581)$. It allows us to claim, that the model meets the condition of homoskedasticity. 
Table 2. Pooled OLS model

\begin{tabular}{|c|c|c|c|c|c|}
\hline & Coefficient & Std. Error & t-ratio & $p$-value & \\
\hline Const & 9.88293 & 0.0572208 & 172.7 & $<0.0001$ & $* * *$ \\
\hline Rail_million_Tkm & $3.26897 e-05$ & $2.38055 \mathrm{e}-06$ & 13.73 & $<0.0001$ & $* * *$ \\
\hline Mean dependent var & 10.42012 & S.D. dependent var & & & 1.227081 \\
\hline Sum squared resid & 222.6795 & S.E. of regression & & & 0.949493 \\
\hline R-squared & 0.403676 & Adjusted R-squared & & & 0.401262 \\
\hline$F(1,27)$ & 188.5679 & $\mathrm{P}$-value(F) & & & $1.07 e-13$ \\
\hline Log-likelihood & -339.4066 & Akaike criterion & & & 682.8132 \\
\hline Schwarz criterion & 689.8481 & Hannan-Quinn & & & 685.6449 \\
\hline Rho & -0.101485 & Durbin-Watson & & & 1.820700 \\
\hline
\end{tabular}

Notes: using 249 observations, included 28 cross-sectional units, time-series length: minimum 6, maximum 10, dependent variable:

l_Road_million_Tkm, Robust (HAC) standard errors

Source: Own processing based on the data of OECD (2021) within the analyzed period 2010-2019 using Gretl statistical program

Wooldridge test for autocorrelation in panel data: Null hypothesis: No first-order autocorrelation (rho $=0)$. Test statistic: $\mathrm{t}(27)=-1.89159$, with $\mathrm{p}$-value $=\mathrm{P}(|\mathrm{t}|>1.89159)=$ 0.0693175 . Autocorrelation is not presented in the model.

We proceeded diagnostics: using $n=28$ cross-sectional units for Fixed-effects estimator, allows for differing intercepts by cross-sectional unit. Joint significance of differing group means: $F(27,220)=1.23498$ with p-value 0.204706. A low p-value counts against the null hypothesis that the pooled OLS model is adequate, favouring the Fixed-effects alternative. This assignment allows us to affirm that the pooled OLS model is not inadequate.

The Hausman test statistic: $\mathrm{H}=22.8979$ with $\mathrm{p}$-value = prob(chi-square $(1)>22.8979)=1.70837 \mathrm{e}-006$. A low p-value counts against the null hypothesis that the Random-effects model is consistent, in favor of the Fixed-effects model. This tests confirms that we could proceed the regression using the Fixed-effects model. The main problem, which impeded the application of this estimator was the presence of autocorrelation.

The model from table 2 can have the following interpretation: if the rail transport performance in millions of tonne-kilometers (the variable of Rail_million_Tkm) is increased by 10 millions (within the analyzed period from 2010 to 2019), the road transport performance (the variable l_Road_million_Tkm) would increase by $0.22 \%$ within the analyzed 10 years period starting with 2010 and finishing with 2019. The claim is valid for the analyzed EU-28 countries. The following table 3 depicts the summary statistics for the analyzed variables.
We also processed the testing of hypothesis for the variable Rail_million_Tkm: $\mathrm{H}_{0}: \beta_{1}=0, \mathrm{H}_{1}: \beta_{1} \neq 0, \mid(0.0220261466-0)$ / $0.0059007935 \mid>2.052 ; 3.73274>2.052$. We reject $\mathrm{H}_{0}$ and claim that the coefficient for the variable Rail_million_Tkm is statistically significant, it means that the rail transport performance in Tkm affects the road transport performance in Tkm.

The model as a whole was also verified for the statistical significance at the level of significance $\alpha=0.1$ by the following: $\mathrm{H}_{0}$ means that the model is not statistically significant, $\mathrm{H}_{1}$ means that the model is statistically significant. The critical value of $\mathrm{F}_{0,1}(1,27)=4.21001$; the calculated $F$ value of the statistics from our model is 188.5679. Since $188.5679>4.21001$, we reject the null hypothesis $\mathrm{H}_{0}$. At the same time, the p-value from our calculations confirms the rejection of the null hypothesis and the acceptance of the alternative hypothesis $\mathrm{H}_{1}$.

We focused on the coefficient of determination, which reaches $R^{2}=0.403676$. It can be said that the regression model with independent variable $\mathrm{x}_{\mathrm{i} 1}$ (Rail transport performance in Tkm within the analyzed 10 years period) explains $40.37 \%$ of the variability of dependent variable $\hat{y}_{i}$ (road transport performance in Tkm-total goods). The remaining $59.63 \%$ of the variability of this variable is due to factors not included in the regression model and random effects. The linear regression model of dependence of road transport performance on the rail transport performance in Tkm is statistically significant.

We enrich our previous research with the regression analysis related to the relationship between road and rail transport assessed by fixed-effects model (table 4). 
Table 3. Summary statistics

\begin{tabular}{lcccc}
\hline Variable & Mean & Median & Minimum & Maximum \\
\hline L_Road_million_Tkm & 10.428 & 10.396 & 7.5224 & 12.887 \\
\hline Rail_million_Tkm & 16433 & 9722.0 & 72.000 & 1.3120 e+005 \\
\hline Variable & Std. Dev. & C.V. & Skewness & Ex. kurtosis \\
\hline L_Road_million_Tkm & 1.2119 & 0.11621 & 0.031694 & -0.25132 \\
\hline Rail_million_Tkm & 23850 & 1.4513 & 3.2144 & 10.944 \\
\hline Variable & $5 \%$ Perc. & $95 \%$ Perc. & IQ range & Missing obs. \\
\hline L_Road_million_Tkm & 8.6612 & 12.631 & 1.3014 & 22 \\
\hline Rail_million_Tkm & 204.22 & 54691 & 16790 & 31 \\
\hline
\end{tabular}

Notes: using the observations 1:01 - 28:10, (missing values were skipped)

Source: Own processing based on the data of OECD (2021) within the analyzed period 2010-2019 using Gretl statistical program

The regression analysis was completed with the following tests: Test for normality of residual - Null hypothesis: error is normally distributed. Test statistic: Chi-square(2) = 14.6357 with $\mathrm{p}$-value $=0.000663587$.

Joint test on named regressors - Test statistic: $F(1,217)$ $=158.662$, with $\mathrm{p}$-value $=\mathrm{P}(\mathrm{F}(1,217)>158.662)=$ $1.14322 \mathrm{e}-027$.

Test for differing group intercepts - Null hypothesis: The groups have a common intercept. Test statistic: $F(27,217)=$ 0.48876 , with $\mathrm{p}$-value $=\mathrm{P}(\mathrm{F}(27,217)>0.48876)=0.985375$

Distribution free Wald test for heteroscedasticity - Null hypothesis: the units have a common error variance. Asymptotic test statistic: Chi-square $(28)=30.5376$ with $\mathrm{p}$-value $=0.337992$. It allows us to claim that the model meets the condition of homoskedasticity.
Wooldridge test for autocorrelation in panel data - Null hypothesis: No first-order autocorrelation (rho $=-0.5$ ). Test statistic: $\mathrm{F}(1,27)=0.912279$ with $\mathrm{p}$-value $\mathrm{P}(\mathrm{F}(1,27)=$ 0.347985 . Autocorrelation is not presented in the model.

Before we made a decision for the Fixed-effects estimator, the following diagnostics was proceeded: using $n=28$ cross-sectional units for Fixed-effects estimator, allows for differing intercepts by cross-sectional unit. Joint significance of differing group means: $F(27,217)=0.48876$ with p-value 0.985375 . A low p-value counts against the null hypothesis that the pooled OLS model is adequate, in favor of the Fixed-effects alternative. This assignment allowed us to affirm that the pooled OLS model was not inadequate, but due to the presence of heteroskedasticity, we also proceeded the Hausman test statistics: $\mathrm{H}=0.247332$ with $\mathrm{p}$-value $=$ $\operatorname{prob}($ chi-square $(1)>0.247332)=0.61896$. A low p-value counts against the null hypothesis that the Random-effects

Table 4. Fixed-effects model

\begin{tabular}{|c|c|c|c|c|c|}
\hline & Coefficient & Std. Error & t-ratio & $p$-value & \\
\hline Const & 3.73893 & 0.0996981 & 37.50 & $<0,0001$ & $* * *$ \\
\hline $\begin{array}{l}\text { L_Rail_Tkm_per_1000_Units_of_ } \\
\text { Current_USD_GDP }\end{array}$ & 0.343566 & 0.0272756 & 12.60 & $<0,0001$ & $* * *$ \\
\hline Mean dependent var & 4.870255 & S.D. dependent var & & & 0.868104 \\
\hline Sum squared resid & 99.97969 & S.E. of regression & & & 0.678775 \\
\hline LSDV R-squared & 0.458495 & Within R-squared & & & 0.422352 \\
\hline LSDV F $(28,217)$ & 6.561959 & P-value(F) & & & $5.95 e-17$ \\
\hline Log-likelihood & -238.3141 & Akaike criterion & & & 534.6281 \\
\hline Schwarz criterion & 636.2827 & Hannan-Quinn & & & 575.5597 \\
\hline Rho & -0.079486 & Durbin-Watson & & & 1.801568 \\
\hline
\end{tabular}

Notes: using 246 observations, included 28 cross-sectional units, time-series length: minimum 6, maximum 10, dependent variable: l_Road_Tkm_per_1000_Units_of_Current_USD_GDP

Source: Own processing based on the data of OECD (2021) within the analyzed period 2010-2019 using Gretl statistical program 
model is consistent in favor of the Fixed-effects model.

The model from table 4 can have the following interpretation: if the rail transport performance (the variable of $l_{-}$ Rail_Tkm_per_1000_Units_of_Current_GDP) is increased by $10 \%$ (within the analyzed period from 2010 to 2019), the road transport performance (the variable l_Road_Tkm_ per_1000_Unit_of_Current_USD_GDP) would increase by $0.79 \%$ within the analyzed 10 years period starting with 2010 and finishing with 2019. The claim is valid for the analyzed EU-28 countries. The following table 5 depicts the summary statistics for the analyzed variables.

We also processed the testing of hypothesis for the variable Rail_Tkm_per_1000_Units_of_Current_USD_GDP: $\mathrm{H}_{0}$ : $\beta_{1}=0, \mathrm{H}_{1}: \beta 1 \neq 0,|(0.343566-0) / 0.0272756|>1.970$; $12.60>1.970$. We reject $\mathrm{H} 0$ and claim that the coefficient for the variable Rail_Tkm_per_1000_Units_of_Current_USD_ GDP is statistically significant, it means that the rail transport performance affects the road transport performance.

The model as a whole was also verified for the statistical significance at the level of significance $\alpha=0.1$ by the following way: $\mathrm{H}_{0}$ means that the model is not statistically significant, $\mathrm{H} 1$ means that the model is statistically significant.
The critical value of $F_{0,1}(28,217)=1.52834$; the calculated $F$ value of the statistics from our model is 6.561959. Since $6,561959>1.52834$, we reject the null hypothesis $H_{0}$. At the same time, the p-value from our calculations confirms the rejection of the null hypothesis and the acceptance of the alternative hypothesis $\mathrm{H}_{1}$.

We focused on the coefficient of determination, too. It reaches $\mathrm{R}^{2}=0.458495$. It can be said that the regression model with independent variable $\mathrm{x}_{\mathrm{i} 1}$ (Rail transport performance within the analyzed ten years period) explains $45.85 \%$ of the variability of dependent variable $\hat{y}_{i}$ (road transport performance). The remaining $54.15 \%$ of the variability of this variable is due to factors not included in the regression model and Random-effects. The linear regression model of dependence of road transport performance on the rail transport performance is statistically significant.

We enrich our previous research with the regression analysis on the relationship between the amount of goods in thousands of tonnes transported by road and by railways (table 6).

The regression analysis was completed with the following tests: Test for normality of residual - Null hypothesis: error is normally distributed. Test statistic: Chi-square(2) =

Table 5. Summary statistics

\begin{tabular}{lcccc}
\hline Variable & Mean & Median & Minimum & Maximum \\
\hline L_Road_Tkm_per_1000_Units_of_Current_USD_GDP & 4,8503 & 4,6974 & 3,4062 & 6,8872 \\
\hline L_Rail_Tkm_per_1000_Units_of_Current_USD_GDP & 3,2894 & 3,7014 & $-1,6861$ & 6,6542 \\
\hline Variable & Std. Dev. & C.V. & Skewness & Ex. kurtosis \\
\hline L_Road_Tkm_per_1000_Units_of_Current_USD_GDP & 0,86109 & 0,17753 & 0,39343 & $-0,95530$ \\
\hline L_Rail_Tkm_per_1000_Units_of_Current_USD_GDP & 1,6650 & 0,50618 & $-0,59990$ & 0,44507 \\
\hline Variable & $5 \%$ Perc. & $95 \%$ Perc. & IQ range & Missing obs. \\
\hline L_Road_Tkm_per_1000_Units_of_Current_USD_GDP & 3,6611 & 6,3665 & 1,4208 & 25 \\
\hline L_Rail_Tkm_per_1000_Units_of_Current_USD_GDP & 0,16493 & 5,8402 & 2,2197 & 33 \\
\hline
\end{tabular}

Notes: using the observations 1:01 - 28:10, (missing values were skipped)

Source: Own processing based on the data of OECD (2021) within the analyzed period 2010-2019 using Gretl statistical program

110.301, with p-value $=1.11818 \mathrm{e}-024$. 'Between' variance $=$ 0 . 'Within' variance $=2.10935 \mathrm{e}+011$, mean theta $=0$.

Joint test on named regressors - Asymptotic test statistic: Chi-square $(1)=399.874$, with p-value $=5.86553 \mathrm{e}-089$.

Breusch-Pagan test - Null hypothesis: Variance of the unit-specific error $=0$. Asymptotic test statistic: Chisquare $(1)=6.34814$, with $\mathrm{p}$-value $=0.0117504$.
Wooldridge test for autocorrelation in panel data - Null hypothesis: No first-order autocorrelation (rho $=-0.5)$. Test statistic: $\mathrm{F}(1,22)=0.0348655$, with $\mathrm{p}$-value $=\mathrm{P}(\mathrm{F}(1,22)>$ $0.0348655)=0.853589$. Autocorrelation is not presented in the model.

The model meets the condition of homoskedasticity due to the application of the robust standard errors when creating the model in Gretl statistical program. 
Table 6. Random-effects model (GLS)

\begin{tabular}{|c|c|c|c|c|c|}
\hline & Coefficient & Std. Error & z & $p$-value & \\
\hline Const & 3.73893 & 0.0996981 & 37.50 & $<0,0001$ & $* * *$ \\
\hline Rail_Tonnes & 7,26760 & 0,363437 & 20,00 & $5,87 e-089$ & $* * *$ \\
\hline Mean dependent var & 556570,5 & S.D. dependent var & & & 714042,4 \\
\hline Sum squared resid & $3,34 \mathrm{e}+13$ & S.E. of regression & & & 435836,4 \\
\hline Log-likelihood & $-2549,000$ & Akaike criterion & & & 5101,999 \\
\hline Schwarz criterion & 5108,352 & Hannan-Quinn & & & 5104,576 \\
\hline Rho & $-0,120817$ & Durbin-Watson & & & 1,410255 \\
\hline
\end{tabular}

Notes: using 177 observations, Included 28 cross-sectional units, time-series length: minimum 3, maximum 8, dependent variable: Road_Tonnes. Robust (HAC) standard errors

Source: Own processing based on the data of OECD (2021) within the analyzed period 2010-2019 using Gretl statistical program

Before we made a decision for the Random-effects estimator, the following diagnostics was proceeded. Joint significance of differing group means: $F(27,148)=0.388642$ with p-value 0.997289. A low p-value counts against the null hypothesis that the pooled OLS model is adequate, favouring the Fixed-effects alternative. This assignment allowed us to affirm that the pooled OLS model was not inadequate, but due to the presence of heteroskedasticity, we could not apply this estimator. The test does not say that we would not be allowed to proceed our analysis using Random or Fixed effects estimators. To decide which estimator select out of these two, we proceeded the Hausman test statistic: $\mathrm{H}$ $=0.587649$ with $\mathrm{p}$-value $=\operatorname{prob}($ chi-square $(1)>0.587649)$ $=0.44333$. A low p-value counts against the null hypothesis that the Random-effects model is consistent, favouring the Fixed-effects model. It means that the Random-effects model is not inadequate in our case.

The model from table 6 can have the following interpretation: if the amount of goods transported by railways (the variable of Rail_Tonnes) is increased by 1000 tonnes (within the analyzed period from 2010 to 2019), the amount of goods transported by road (the variable Road_ Tonnes) would increase by 7270 tonnes within the analyzed ten years period starting with 2010 and finishing with 2019. The claim is valid for the analyzed EU-28 countries. The table 7 depicts the summary statistics for the analyzed variables.

Based on the p-value of individual regression coefficients, we argue that the linear regression model of dependence of the amount of goods transported by road on the amount of goods transported by railway is statistically significant.

Figure 1 displays the transport performance of the railway, road and inland waterway transport of goods as a percentage of total transport performance within the EU-28 countries. The importance of the combined transport solutions, in which road transport and the railway and/or inland waterway transport modalities are also enhanced from the ecological point of view. The most dominant position in almost all of these countries has the road transport with a small exception of only two countries - Latvia and Lithuania, where the most dominant position has the railway transport of goods in Tkm. Table 8 compares the average utilization of freight transport vehicles in tonnes within the EU-28 countries.

The calculations are made as a ratio between the measures of millions of vehicle-kilometers and millions of tonne-kilometers. The most utilized road transport vehicles are in Finland, Estonia, Bulgaria, Sweden, Lithuania, Spain, and Slovenia. The less utilized ones are in the United Kingdom, Ireland, and Slovakia.

Figure 1. Transport performance according to transport modes

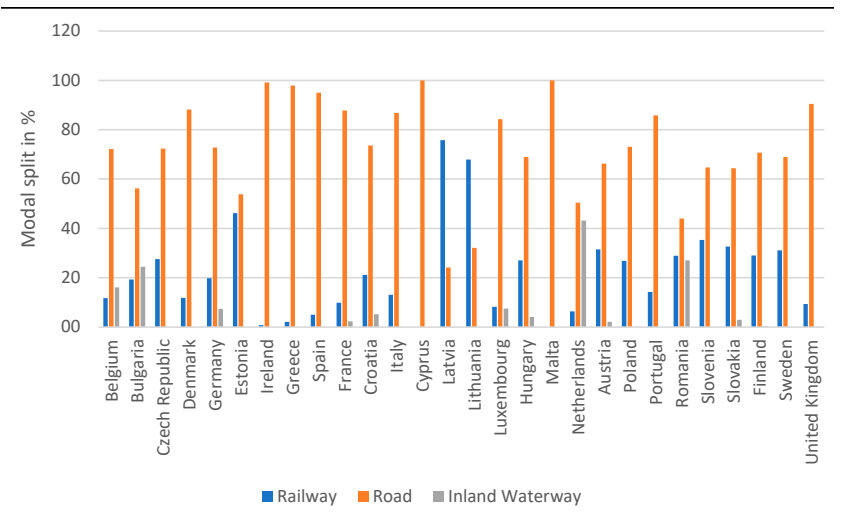

Source: Own processing based on the data of Eurostat (2018) using MS Excel 
Table 7. Summary statistics

\begin{tabular}{lcccc}
\hline Variable & Mean & Median & Minimum & Maximum \\
\hline Road_Tonnes & $5.3593 \mathrm{e}+005$ & $2.1611 \mathrm{e}+005$ & 14402. & $3.2082 \mathrm{e}+006$ \\
\hline Rail_Tonnes & 63687 & 47358 & 540.00 & $3.7474 \mathrm{e}+005$ \\
\hline Variable & Std. Dev. & C.V. & Skewness & Ex. kurtosis \\
\hline Road_Tonnes & $7.0462 \mathrm{e}+005$ & 1.3148 & 2.0313 & 3.8721 \\
\hline Rail_Tonnes & 77825 & 1.2220 & 2.5878 & 6.9194 \\
\hline Variable & $5 \%$ Perc. & $95 \%$ Perc. & IQ range & Missing obs. \\
\hline Road_Tonnes & 29139 & $2.0041 \mathrm{e}+006$ & $5.5418 \mathrm{e}+005$ & 11 \\
\hline Rail_Tonnes & 1373.0 & $2.3420 \mathrm{e}+005$ & 71501 & 103 \\
\hline
\end{tabular}

Notes: using the observations 1:01 - 28:10, (missing values were skipped)

Source: Own processing based on the data of OECD (2021) within the analyzed period 2010-2019 using Gretl statistical program

Table 8. Average utilization of freight transport vehicle in tonnes across the EU-28 countries

\begin{tabular}{llll}
\hline Country & Tonnes per vehicle & Country & Tonnes per vehicle \\
\hline Belgium & N/A & Croatia & 15,38976857 \\
\hline Bulgaria & 16,43292683 & Italy & 15,76811411 \\
\hline Czech Republic & 11,41550862 & Cyprus & 12,56338028 \\
\hline Denmark & 11,27669173 & Latvia & 15,83632524 \\
\hline Germany & 13,29801436 & Lithuania & 16,3258427 \\
\hline Estonia & 16,45299145 & Luxembourg & 15,88785047 \\
\hline Ireland & 11,24031008 & Hungary & 14,27153065 \\
\hline Greece & $\mathrm{N} / \mathrm{A}$ & Netherlands & 12,66568591 \\
\hline Spain & 16,14497061 & Austria & 14,62145289 \\
\hline France & 12,32733608 & Poland & $\mathrm{N} / \mathrm{A}$ \\
\hline Portugal & 14,95598911 & Finland & 17,47533909 \\
\hline Romania & 14,62105001 & Sweden & 16,38206481 \\
\hline Slovenia & 16,08176556 & United Kingdom & 10,23191667 \\
\hline
\end{tabular}

Source: Own processing based on the data of Eurostat (2018) using MS Excel

\section{Conclusion}

The main objective of this paper was to analyze the importance of bimodal combined solutions in the rail-road transport of goods with an emphasis on the aspect of ecology within the geographical region of EU-28 countries. This objective was achieved by an in-depth analysis of panel data over the ten years period 2010 - 2019 from OECD and Eurostat, which deal with the freight transport performance in tonne-kilometers, the freight transport performance in tonne-kilometers per one thousand units of current USD GDP and the amount of goods transported in thousands of tonnes, all three for the rail and road transport modalities. Within this analysis, a direct relationships between the freight road and rail transport performance in Tkm, between the freight road and rail transport performance in tonne-kilometers per one thousand units of current USD GDP and between the amount of goods in thousand of tonnes transported by road and rail transport modes were confirmed. These dependencies have three linear regression models that allow us to accept the following hypothesis: The transport of goods in the EU-28 countries is being realized in environmentally friendly combined transport solutions (the combination of the road and railway transport mode). 
The existence of these three separate models (Pooled OLS, Fixed-effects and Random-effects) allows us to argue that our hypothesis is confirmed from different points of view represented by the OECD and Eurostat data. In other words, there is a preference of the combined road transport as a short pre- and/or post-transport with predominantly the railway transport as a main carrier within the intermodal solutions.
Our further research will focus on freight rail-road combined transport in the modern logistic systems using the same sample of EU-28 countries within the same period of the last decade. We will consider the case of Switzerland's piggybacking in the rail-road intermodal transport as a sustainable pattern (UNECE, 2018).

\section{References}

Banister, D. (2018). Policy on Sustainable Transport in England: The Case of High Speed 2. European Journal of Transport and Infrastructure Research, 18(3), 262-275.

Bierwirth, Ch., Kirschstein, T., \& Meisel, F. (2014). On Transport Service Selection in Intermodal Rail/Road Distribution Networks. Business Research, 5(2012), 198-219. https://doi.org/10.1007/BF03342738

Carboni, A., \& Dalla Chiara, B. (2018). Range of technical-economic competitiveness of rail-road combined transport. European Transport Research Review, 10(2), 45. https://doi.org/10.1186/s12544-018-0319-3

Cavallaro, F., Nocera, S., \& Sommacal, G. (2021). Appropriateness of the "small-scale corridorterminals" scheme for rail-road combined transport: Evidence from the Brenner axis. Research in Transport Economics, 100995. https://doi.org/10.1016/j.retrec.2020.100995

European Comission. (2020). Multimodal and combined transport. Retrieved from https://ec.europa.eu/transport/themes/logistics-and-multimodal-transport/multimodal-and-combined-transport_ro

Eurostat.(2018).Road transport.Retrieved from https://ec.europa.eu/eurostat/data/database?p_p_id=NavTreeportletprod_WAR_NavTreeportletprod_INSTANCE_nPqeVbPXRmWQ\&p_p_lifecycle=0\&p_p_state=normal\&p_p_mode $=$ view\&p_p_col_id $=$ column- 2 \& $\bar{p}_{-}$_p_col_ pos $=1 \&$ p_p_col_count $=\overline{2}$

Eurostat. (2020). Gross domestic product at market prices. Retrieved from https://ec.europa.eu/eurostat/databrowser/view/tec00001/ default/table?lang=en

Forkenbrock, D. J. (2001) Comparison of external costs of rail and truck freight transportation. Transportation Research Part A: Policy and Practice, 35(4), 321-337. https://doi.org/10.1016/S0965-8564(99)00061-0

Furdová, L., \& Hansenová, H. (2013). Logistika ako pridaná hodnota pre zákazníka v globálnej ekonomike. Bratislava: Ekonóm, 121.

Green Modal Transport. (2019). What is the modal shift? Retrieved from http://www.greenmodal.eu/en/content/what-modal-shift

Hanssen, T. E. S. \& Mathisen, T. A. (2011) Factors facilitating intermodal transport of perishable goods - transport purchasers viewpoint. European Transport - Trasporti Europei, 49(2011) 75-89.

Hansenová, H. (2007). Prepravné služby v podmienkach medzinárodného obchodu. Bratislava: Ekonóm, 124.

INTERREG. (2020). Overview of the combined transport market in the BSR. Retrieved from https://www.combine-project.com/sites/default/ files/content/resource/files/200228_combine_output_2.1_overview_of_the_ct_market_in_the_baltic_sea_region.pdf

IRU. (2020). Combined transport. Retrieved from https://www.irumobilitypackages.org/combined-transport

Kurtuluş, E., \& Bilge Cetin, İ. (2020). Analysis of modal shift potential towards intermodal transportation in short-distance inland container transport. Transport Policy, 89(4), 24-37. https://doi.org/10.1016/j.tranpol.2020.01.017

Mathisen, T.A., \& Hanssen, T.E.S. (2014). The Academic Literature on Intermodal Freight Transport. Transportation Research Procedia, 3(2014), 611-620. https://doi.org/10.1016/j.trpro.2014.10.040

Matthias, V., Bieser, J., Mocanu, T., Pregger, T., Quante, M., Ramacher, M.O.P., Seum, S., \& Winkler, Ch. (2020). Modelling road transport emissions in Germany - Current day situation and scenarios for 2040. Transportation Research Part D: Transport and Environment, 87(10), 102536. https://doi.org/10.1016/j.trd.2020.102536

Minárik, M. (2019). Multimodal Transport of Dangerous Goods and its Impact on the Ecology: The Case of EU. Nové výzvy a súčasné problémy presadzovania zahraničnoobchodných záujmov EÚ ovplyvnené geopolitickými zmenami: (s implikáciami na ekonomiku SR). Bratislava: Ekonóm, 2019, pp. 91-105.

OECD. (2021). Freight Transport: Inland Freight Transport. Retrieved from https://stats.oecd.org/

OECD. (2021). Indicators: Transport measurement. Retrieved from https://stats.oecd.org/\#

Park, S. (2020). Quality of transport infrastructure and logistics as source of comparative advantage. Transport policy, 99(12), 54-62. https://doi.org/10.1016/j.tranpol.2020.07.016

Rail Freight. (2019). Road and rail work together on liability of combined transport. Retrieved from https://www.railfreight.com/ policy/2019/03/26/road-and-rail-work-together-on-liability-of-combined-transport/?gdpr=accept

Široký, J., Schröder, S. \& Gašparík, J. (2017). Comparison of Operational and Economic Aspects of Direct Road Transport and Continental Combined Transport. Communications: scientific letters of the University of Žilina, 19(2), 109-115. ISSN 1335-4205.

UIC. (2020). Combined transport. Retrieved from https://uic.org/freight/combined-transport/ 
UIRR. (2020). 2020 Report on Combined Transport (CT). Retrieved from https://uic.org/IMG/pdf/2020_combined_transport_report_press conference_202010230.pdf

UIRR. (2020). Road-Rail CT. Retrieved from http://www.uirr.com/en/road-rail-ct.html

UNECE. (2018). Railway's role in intermodality and the digitalization of transport documents. Retrieved from https://unece.org/DAM/trans/ main/wp24/ECE_TRANS_262_E_Web_Optimized.pdf

\section{Acknowledgment}

This paper is a part of research projects VEGA n.1/0420/19 and VEGA n. 1/0039/20.

\section{Trajnostni transport blaga z uporabo rešitev kombiniranega transporta}

\section{Izvleček}

Ta članek analizira pomen bimodalnih rešitev v železniško-cestnem transportu blaga s poudarkom na ekološkem vidiku znotraj geografske regije EU-28. Z uporabo panelne regresije podatkov za obdobje od 2010 do 2019 poskušamo potrditi odvisnost med cestnim in železniškim transportom blaga z uporabo več meril tovornih enot: uspešnost tovornega transporta $\mathrm{v}$ tonskih kilometrih, uspešnost tovornega transporta v tonskih kilometrih na tisoč USD in količina prevoženega blaga v tisočih tonah. Aplikacija podatkov na vsa izbrana merila tovornih enot v regresijskem modelu potrjuje povezavo med cestnim in železniškim transportom. Neposredna povezava med tema dvema oblikama transporta potrjuje učinek komplementarnosti, ki pomeni, da v večini primerov rešitve transporta blaga zahtevajo kombinacijo prevoznih sredstev po cesti in železnici, pri čemer je treba obravnavati železnico kot glavno transportno sredstvo, cestni transport pa mora imeti vlogo kratkega pretovora ali premeščanja. Ker je železniški transport mogoče obravnavati kot okolju prijazen, so takšne bimodalne rešitve pomembe tudi z ekološkega vidika.

Ključne besede: bimodalnost, kombinirani transport blaga, ekologija, Evropska unija 